\title{
The balance of power between food manufacturers and retailers
}

\author{
Jacqueline L. Spence* \& A.W.F. Fourie \\ Graduate School of Business Administration, University of the Witwatersrand, P.O. Box 98, WITS 2050, Republic of South Africa
}

Received October 1994

\begin{abstract}
There is an ongoing debate as to who in the South African food sector holds the most power - the manufacturer or the retailer. This debate becomes particularly heated at times when the price of food is seen to be rising disproportionately to the overall inflation rate, as evidenced in 1991 . This research contributes to the debate surrounding the balance of power. The overall balance of power is seen to be made up of three components: power - the ability of member $A$ to alter the decisions of member B; non-coercive sources of power - the ability to give assistances/rewards; and coercive sources of power - the ability to apply punishments. It was found that manufacturers are strongest on the power dimension, retailers have the greatest strength in the coercive sources of power dimension, and neither retailers nor manufacturers have the upper hand in respect of non-coercive sources of power. The overall balance of power is, however, perceived to be dynamic in nature and likely to change in future due to issues such as changing consumer profiles and the installation and commissioning of sophisticated information systems by retailers.
\end{abstract}

Daar is 'n voortgesette debat om te besluit wie in die Suid Afrikaanse voedselsektor die meeste mag het - die vervaardiger
of die kleinhandelaar. Hierdie debat word besonder vurig as die prys van voedsel oneweredig styg in vergelyking met die
algemene inflasiekoers, soos wat in 1991 gebeur het. Hierdie navorsing dra by tot die debat oor magsewewig. Die algemene
magsewewig bestaan uit drie dele: mag - die vermoë van lid A om die besluite van lid B te verander; nie-dringende bronne
van mag - die vermoë om hulp/belonings te gee; en dringende bronne van mag - die vermoë om straf uit te deel. Daar is
bevind dat vervaardigers die sterkste staan betreffende mag, dat kleinhandelaars die grootstc, dringende bronne van mag het
en dat nòg vervaardigers nòg kleinhandelaars die oorhand het met betrekking tot nie-dringende bronne van mag nie. Die
magsverwantskap word as dinamies beskou en sal waarskynlik in die toekoms verander vanweë verandering in die tipe van
verbruiker en die gebruik van gesofistikeerde inligtingstelsels deur die kleinhandelaars om straf toe te dien.

*Author to whom correspondence should be addressed.

\section{Introduction}

In 1991, when food prices started rising well ahead of the overall inflation rate, the attention of the media, government institutions, consumer bodies and the manufacturing and retailing sectors was focused on finding the culprit(s). According to the Financial Mail (1 November 1991: 94) the producer price index for food escalated from 100 in August 1985 to 222.8 in August 1991, an overall rise of $122.8 \%$. During the same period the overall consumer price index for food rose from 100 in August 1985 to 241.9 in August 1991, an overall rise of $141.9 \%$. The Board on Tariffs and Trade (BTT) (1992: 6) identified the main factors contributing towards price divergence, namely input cost inflation at the food processing level in the chain (2\% p.a.), Control Board schemes ( $1.5 \%$ p.a.), withdrawal of subsidies $(0.3 \%$ p.a.), removal of price control ( $0.2 \%$ p.a.) and others ( $1.1 \%$ p.a.). According to the BTT (1992: 6), it would therefore be fair to say that the extraordinary rise in food prices has the distribution channel from manufacturer to retailer, and not the farmer, as origin. Consequently, the power relationships in the food distribution channel, and the bearing it has on competition and food prices, are of more than just academic importance.

Although the BTT study (1992: 6) into the price mechanism in the food chain claims that the available statistical data does not lend support to the argument that excessive profit taking by firms in the food chain is the cause of price divergence or rising food prices, it goes on to say that the average profit margins (before interest and tax) of listed food processing companies improved on a percentage basis over the past five years, relative to the five years before.
On the other hand, analysis of the results of certain of the major food retailers show a modest return on turnover, with a declining rather than increasing trend (Mc Gregor's Quick Reference to the JSE, May 1991).

One of the reasons for the difference in profitability trends between manufacturers and retailers may be changes in the traditional power relationship. According to Harisunker of Checkers and Summers of Pick 'n Pay (The Future of Retailing, Supplement to Financial Mail 26 April 1991: 14), and Lamberti of Makro (personal interview, May 1992) the balance of power in the food distribution channel has swung back from the retailer to the manufacturer over the last few years. This has led to a weakening of the ability of retailers to demand low prices from manufacturers. This is of course the view of retailers, and may not be agreed with by manufacturers.

With this study we contribute to the debate around food distribution in South Africa by conducting research into power in the food distribution channels.

\section{Review of the literature on power}

In assessing where the balance of power lies, it is necessary to understand what is meant by power. Many definitions of power have been proposed by different writers. All of these seem to start off with, as baseline, the work of Dahl, a political scientist. Dahl stated:

'If everyone were perfectly agreed on ends and means, no one would ever need to change the way anyone else behaved. Hence no relations or influence or power would arise. Hence no political system would exist. Let one person frustrate another in the pursuit of his goals, and you already have the germ of a political 
system. For the one may then try to change the behaviour of the other. If he does so by creating the expectation of sizable rewards or deprivations, then relations of power come into existence' (1963: 72).

Gaski proposed as an expression of the underlying theme: 'the ability to evoke a change in another's behaviour. In other words, power is the ability to cause someone to do something he would not have done otherwise' (1984: 10).

Various authors seem to be in agreement concerning the application of the basic concept of power in the marketing context:

'Power refers to the ability of one channel member to induce another channel member to change its behaviour in favour of the objectives of the channel member exerting influence'(Wilemon, 1972: 12 2).

'Power can be regarded as the ability of.a firm to affect another's decision making and/or overt behaviour' (Wilkinson, 1974: 12).

The definition put forward by El-Ansary \& Stern, being perceived to be representative of the literature in this area, was accepted as baseline for purposes of this study:

'... the power of a channel member is his. For this control to qualify as power, it should be different from the influenced member's original level of control over his own marketing strategy' (1977: 47-52).

A popular classification of power, often used in negotiation and selling skills programs and academic courses, is that proposed by French \& Raven (1959), namely reward, coercive, legitimate, referent and expert sources of power. Levy \& Zaltman in James (1985: 14) provide a summary of power bases in the buyer-seller dyad as seen in Table 1 .

According to Lusch (1976) the coercive sources can be differentiated from the others, because they alone involve potential punishment and therefore the individual begrudgingly yields power to another. Many writers, such as Hunt \& Nevin (1974), have therefore grouped the other four sources under the heading non-coercive sources of power and used the coercive/non-coercive classification. The validity of coercive and non-coercive sources of power as constructs was demonstrated by various authors, such as Hunt \& Nevin (1974) and Lusch (1976). The coercive versus non-coercive classification of sources of power was used in this study, with coercive sources of power operationalized as the 'perceived likelihood of application of punishments' by other channel members in the cases where the goals of the channel members differ, and the 'damage that could be caused by such punishments' if they were to be applied. Non-coercive sources of power were operationalized as the 'perception of the quality of assistances' offered by the other channel member, and the 'importance of these assistances' (Lusch, 1976: 385; Wilkinson, 1981: 18; Lusch \& Brown, 982: 318; Gaski, 1984: 21-26).

Gaski (1984) points out that power is generally considered a function of the perception of power bases, e.g. "promise of reward' or 'ability to satisfy'. He concludes that it may be more correct to regard the perception itself as the source of power.

Other important conceptual issues which warrant closer attention are those of 'sources of power' versus 'power' and
Table 1 Power bases in the buyer-seller dyad

\begin{tabular}{|c|c|c|}
\hline Type of power: & Seller: & Buyer: \\
\hline $\begin{array}{l}\text { Legitimate power } \\
\text { bases: e.g. contractual } \\
\text { agreement }\end{array}$ & $\begin{array}{l}\text { Authority to negotiate } \\
\text { terms and conditions }\end{array}$ & $\begin{array}{l}\text { Authority to negotiate } \\
\text { terms and conditions }\end{array}$ \\
\hline $\begin{array}{l}\text { Expert power bases: } \\
\text { e.g. superior } \\
\text { knowledge or insight }\end{array}$ & $\begin{array}{l}\text { Knowledge about needs } \\
\text { of buying company }\end{array}$ & $\begin{array}{l}\text { Knowledge about needs } \\
\text { of buying company }\end{array}$ \\
\hline $\begin{array}{l}\text { Reward power bases: } \\
\text { e.g. ability to mediate } \\
\text { rewards }\end{array}$ & $\begin{array}{l}\text { Offering scarce } \\
\text { information on } \\
\text { markets, products. } \\
\text { competition } \\
\text { Offering entertainment } \\
\text { to the buyer himself }\end{array}$ & $\begin{array}{l}\text { Offering worthwhile } \\
\text { leads } \\
\text { Offering entertainment } \\
\text { to the seller himself }\end{array}$ \\
\hline $\begin{array}{l}\text { Referent power bases: } \\
\text { e.g. seeking to share } \\
\text { the reputation of } \\
\text { another company }\end{array}$ & $\begin{array}{l}\text { Perceived importance } \\
\text { and strength of buyer's } \\
\text { image } \\
\text { Successful interpersonal } \\
\text { techniques of } \\
\text { ingratiating }\end{array}$ & $\begin{array}{l}\text { Perceived importance } \\
\text { and strength of seller's } \\
\text { image } \\
\text { Successful interpersonal } \\
\text { techniques of } \\
\text { ingratiating }\end{array}$ \\
\hline \multirow{2}{*}{$\begin{array}{l}\text { Coercive power bases: } \\
\text { e.g. ability to punish } \\
\text { the other party }\end{array}$} & $\begin{array}{l}\text { Threat of delays or } \\
\text { increased price }\end{array}$ & $\begin{array}{l}\text { Threat of withdrawing } \\
\text { business from supplier }\end{array}$ \\
\hline & $\begin{array}{l}\text { Threat of quality or } \\
\text { service problems at a } \\
\text { lower price } \\
\text { Threat of insufficient } \\
\text { supply }\end{array}$ & $\begin{array}{l}\text { Threat of reducing } \\
\text { order quantities }\end{array}$ \\
\hline
\end{tabular}

'exercised' versus 'unexercised power' . Gaski summarizes as follows:

'Exercised power refers to actually altering a channel member's behaviour while unexercised power refers to the ability to alter another channel member's behaviour. Researchers have often tended to measure the construct "power" as if it were defined as exercised power, while they have actually accepted the latter as definition for power' (1984: 24).

The exercise of 'power sources' on the other hand refers to an activity, e.g. the granting of rewards or imposition of punishments, while the exercise of 'power' refers to a result or outcome, e.g. alteration of another's behaviour irrespective of the means used to accomplish it.

An interesting concept proposed by Gaski (1984) and which was later modified somewhat for use in conflict measurement by Moore (1990) is the 'volume' of power. Power is 
represented in three dimensional space by the ability of $A$ to influence any number of B's decisions, the extent to which $A$ can accomplish influence and the extent to which $\mathbf{A}$ can decide on when to do so.

For the purpose of this study power and sources of power are thus defined as follows.

- Power is operationalized as the 'ability of member $A$ to alter the decisions' of channel member $B$. The concept of a 'volume' of power is accepted for purposes of this study, although only in a two dimensional format. Therefore, not only is the extent of the ability to alter channel member B's decisions measured, but also which decisions may be altered (Gaski, 1984). The time dimension (i.e. when such decisions may be altered) is neglected due to the difficulty of operationalizing that concept.

- Sources of power is viewed as the ability to impose rewards or punishments. Power means the ability, not the inability, to alter behaviour whereas a source of power is an ability to impose a reward and may not necessarily lead to actual change. Sources of power are divided into noncoercive and coercive sources.

\section{Methodology}

The purpose of this study was to contribute to the debate around food distribution in South Africa by conducting research into power in the food distribution channel. Specifically the aim was to test the hypothesis that the power balance in food retailing in South Africa is currently in the hands of the manufacturer, and to characterize channel conflict and power in food distribution in South Africa.

The population under study was thus the major members of the food distribution channel in South Africa. This is depicted in Appendix 1.

A questionnaire was used as the measuring instrument. Special care was taken to use constructs which are both consistent with accepted definitions and which have been shown in previous research (Gaski, 1984; Hunt \& Nevin, 1974; Etgar, 1976; Lusch \& Brown, 1982; Brown \& Day, 1981) to be valid constructs. The questionnaire was pilot tested with three retailers and three wholesalers. The questionnaire consisted of four sections:

\section{Section A}

Demographic information

\section{Section B}

Questions on coercive sources of power. The likelihood of the application of different possible punishments against the respondent's company is measured, as well as the perceived damage that these punishments could do to the profitability of the company if they were to be applied.

The possible punishments that manufacturers may apply to retailers are:

- Deliver stock late

- Take legal action

- Charge comparatively high prices

- Stop supplying the retailer

- Reduce the retailer's credit terms

- Supply poor quality products
The possible punishments that retailers may apply to manufacturers are:

- Delay acceptance of delivery

- Take legal action

- Demand comparatively lower prices

- Delist the manufacturer's products

- Refuse to pay as per the agreed terms

- Reduce allocated shelf space

\section{Section C}

Measures the non-coercive sources of power. The respondent is asked to describe the quality of the various 'assistances' offered to his company and the importance of these assitances in terms of profitability.

The possible assistances which may be offered by retailers are:

- Provision of product information

- Provision of market information

- Advertising coverage of products

- Sales promotions on products

- Adequate notice before delivery

The possible assistances which may be offered by manufacturers are:

- Provision of product information

- Provision of market information

- Advertising support

- Support of sales promotions

- Replenishment of 'shelf-stock

\section{Section D}

Measures power, i.e. the ability of the other party to change decisions taken by the respondent's company regarding important retailing issues.

The manufacturer's decisions which may be changed by retailers are:

- Delivery lead time, i.e. stock to have on hand

- Sponsorship budgets for sales promotions

- How to allocate advertising spending

- Whether or not to supply house brands

- Setting prices

- Setting delivery policy

- Product packaging decisions

The retailer's decisions which may be changed by manufacturers are:

- Amount of stock to hold

- How much to spend on sales promotions

- How to allocate advertising spending

- Allocation of shelf space to products

- Determining markup percentages

- Setting the rules of delivery to company warehouses

- Deciding where to place products in the store

The perceived change in the power relationship over the last ten years, and the expected future changes are queried by means of open-ended questions.

For each of the sections B and D, a five point Likert scale was used. Likert scale data is ordinal rather than interval, and thus needs to be rescaled.

A further section on conflict in the distribution channel was included. This is only reported on here in terms of its use in 
determining the validity of the power and sources of power measures.

Questionnaires were sent to three retailers and three wholesalers for comment and discussion. Thereafter a total of thirty manufacturers and thirty retailers were contacted by telephone and requested to complete the questionnaire, which was then faxed to them. A further hundred questionnaires were posted to both retailers and manufacturers. Telephone follow-ups were used to ensure an adequate response rate. Due to the sensitive nature of the power relationship between retailers and manufacturers, respondent anonymity was believed to be essential in order to achieve a reasonable response rate. As was the case with previous studies in this field no comparisons of respondents and non-respondents could therefore be made. Questionnaires were distributed roughly in proportion to the turnover of the different companies or group of companies.

The data from the questionnaires was rescaled using Correspondence Analysis in order to convert ordinal data to interval data, and thus allow mathematical manipulation of the data. The work of Lusch \& Brown (1982) and Brown \& Day (1981) was then used as a reference for the design of appropriate indices for the constructs. Brown \& Day (1981), in a study to establish improved methods of operationalizing manifest conflict, measured three variables with reference to fifteen 'sensitive issues', namely frequency of disagreement over each issue, intensity of disagreement and the importance of each issue (with reference to profitability). By using different combinations of the three variables, six alternative measures were formed. Brown \& Day (1981) concluded that the best measures for conflict were the importance of each issue multiplied by the frequency of each disagreement, or the intensity of each disagreement.

Thus non-coercive sources of power were measured by multiplying the respondent's perception of the quality of the assistances by the importance rating of such assistances, and expressed on a ten point linear scale. Coercive sources of power were measured by multiplying the likelihood of application of punishments by the damage that such punishments could do to the profitability of the company, and expressed on a five point linear scale. Power was measured by means of the rescaled five point Likert scale.

Manufacturer and retailer data were treated as two separate samples. T-tests and the Mann-Whitney test were applied to the above data to determine any differences between wholesalers and manufacturers.

The data was analyzed for content, construct, discriminant and convergent validity. This study also measured conflict between manufacturers and retailers. The results of this are not reported here, except in terms of their usage in the determination of validity.

Content validity refers to the degree to which a measure covers the range of meanings within the concept (Babbie, 1989). Content validity was ensured by basing the design of the constructs on previous research, and by obtaining feedback from respondents in the initial pilot study.

Construct validity 'attempts to identify the underlying construct(s) being measured and determine how well the test represents them' (Emory \& Cooper, 1991: 184). Construct validity for coercive and non-coercive sources of power and power were tested by the correlation that existed between these sources and conflict for similar issues. The correlations were generally low, but of the right sign. This is similar to the results experienced by Lusch (1976).

Discriminant validity on the sources of power was tested by running a factor analysis on the coercive together with the non-coercive sources of power. The variables of the different sources of power loaded onto different factors, indicating discriminant validity. Similarly, the results of a factor analysis of the sources of power and the variables of power indicated discriminant validity.

Convergent validity is indicated when two maximally different measures of the same concept are highly correlated. Correlation analysis, in the case of coercive sources of power, between the likelihood of application of punishment and the composite measure (likelihood of application times damage that could result), and between the damage that could result from the application of the punishment and the composite measure, yielded significant positive correlations for each variable. Thus convergent validity may be assumed. Similarly, for non-coercive sources of power, correlation analysis between the measures for non-coercive sources of power and the composite measure, indicated convergent validity. Convergent validity could not be measured in the case of power.

\section{Discussion of results}

An overall return rate of $23 \%$ was received. This is in line with that encountered by, amongst others, Hunt \& Nevin (1974) - 26\%, and Etgar (1978) - 19\%.

For the retailer sample, the responses per store were: Shoprite \& Checkers: $12 \%$

Pick 'n Pay: $\quad 20 \%$

Makro: $\quad 12 \%$

OK/Hyperama: $\quad 16 \%$

Spar: $\quad 20 \%$

Other: $\quad 8 \%$

The distribution of respondents per job category was:

Owners of stores, (such as Spar franchisees): $12.9 \%$

Head office management:

$16.1 \%$

Store management:

$45.2 \%$

Buyers:

$22.6 \%$

Other:

$3.2 \%$

For the manufacturer sample, the distribution of respondents per job category was:

Owners(including MD's):

Sales managers: $\quad 34.5 \%$

Other: $\quad 6.23 \%$

No indication of job given: $9.68 \%$

Many manufacturers chose not to indicate their company name, therefore no sensible distribution can be given apart from noting that responses were received from a variety of companies, covering the categories of cold storage, edible oils, milling, eggs, chickens, confectionery, dried foods, frozen foods, sugar, processed meat, bottled foods, canned foods, dairy and fish. One reason for many respondents' apparent unwillingness to disclose their company name may be a fear of a weakening in their bargaining position, should their responses become known to retailers. 
Table 2 Coercive sources of power

\begin{tabular}{lcll}
\hline $\begin{array}{l}\text { Retailer's coercive sources of } \\
\text { power: }\end{array}$ & Mean & $\begin{array}{l}\text { Manufacturer's coercive sources of } \\
\text { power: }\end{array}$ & Mean \\
\hline Demand comparatively lower prices & 4.28 & Charge comparatively high prices & 2.66 \\
Delist manufacturer's products & 3.69 & Deliver stock late & 2.33 \\
Reduce allocated shelf space & 3.65 & Supply poor quality products & 2.16 \\
Refuse to pay as per agreed terms & 3.17 & Stop supplying products & 1.93 \\
Delay acceptance of delivery & 2.67 & Reduce retailer's credit terms & 1.64 \\
Take legal action & 1.88 & Take legal action & 1.35 \\
\hline
\end{tabular}

In order to compare the coercive sources of power for manufacturers and retailers, the results for each possible coercive source of power were summed over all the respondents and the average for each variable calculated. The results are shown in rank order in Table 2 (on a five point scale).

Inspection of Table 2 seems to indicate that retailers have stronger coercive sources of power than manufacturers, since the overall ratings which manufacturers give the coercive sources of power of retailers are higher than vice versa. Application of both T-tests and the Mann-Whitney test indicate that there are significant differences between the sample means for the sources of power which have to do with:

- price

- product supply/delisting

- credit terms.

In each of these cases the means of the sample obtained from the manufacturers are higher. Therefore, manufacturers rate the coercive sources of power held by retailers higher than retailers rate the coercive power of manufacturers, on each of these issues.

Both a T-test and a Mann-Whitney test on the sum of all the coercive sources of power for retailers and manufacturers indicates that manufacturers rated the coercive power of retailers overall significantly higher than retailers rated that of manufacturers. In other words, retailers are high on the ability to apply punishments that may hurt manufacturers. This is consistent with the authors' general experience of the food retailing market - it is known that manufacturers often complain of being threatened that retailers may delist their products in cases of goal divergence. Similarly, they complain that retailers often demand unreasonably low prices. It came as no surprise that these two coercive sources of power should receive the highest rating from manufacturers. Pick 'n Pay started this trend in the seventies by taking an aggressive stance to force manufacturers to cut prices. To be delisted could spell financial disaster to a manufacturer. Clive Weil referred to this situation as 'commercial terrorism', and said: 'I find it impossible to treat the customer as queen, my staff as royalty, but my suppliers as dirt' (The Name of the Game, 26 April 1991: 14). The foundation for this strong position in which retailers apparently find themselves in lies in the strong concentration in the retail sector, with a good $56 \%$ of all foods being sold through the chains (Davies et al., 1985). The advent of house brands adds to the leverage retailers have over suppliers.

Yet, the margins retail chains operate on seem to be on the decline. This seems to be in contrast to their strong coercive sources of power which should allow retailers to bargain for favourable prices and payment terms. Some possible explanations for this apparent contradiction are:

- Strong intra-group competition forces retailers to keep margins low and rather compete on efficiency of operation.

- Shrinkage tends to increase during difficult economic times, as has been experienced in the recent past.

- Trade unions have negotiated more favourable conditions of employment for their workers and increased pressure on margins through industrial action.

In order to compare the non-coercive sources of power for manufacturers and retailers, the results for each possible noncoercive source of power were summed over all the respondents and the average for each variable calculated. The results are shown in rank order in Table 3 (on a ten point scale).

Both retailers and manufacturers rate sales promotion and advertising as the most important non-coercive sources of power. This is consistent with what one might expect. Application of T-tests and the Mann-Whitney test result in the Mann-Whitney test only indicating a difference in the sample means on the issue of provision of market information. These results indicate that neither the retailer nor the manufacturer hold a clear advantage when it comes to non-coercive sources of power. A possible explanation is that retailers and manufacturers need to co-operate on a partnership basis when it comes to advertising, promotion, etc. In many ways, this is the only part of the relationship visible to the consumer.

The apparent contradiction in terms of the strong coercive power of the retailers and the declining margins may be explained by the results on power. The results for each power variable were summed over all the respondents and the average for each variable calculated. The results are shown in rank order in Table 4 (on a five point scale). The results indicate the ability of one party to change decisions of the other party regarding certain key retailing issues.

It can clearly be seen from these results that retailers rate the power of manufacturers higher than the manufacturers rate the power of retailers. Both T-tests and a Mann Whitney test indicate that significant differences in perceived power exist in the cases of delivery policy, allocation of advertising spending, spending on sales promotion and the allocation of shelf space, with the manufacturers perceived to have significantly higher power. Since the overall rating for the power of the manufacturers is also significantly higher than that for retailers, it can be concluded that the power in the food distribution channel is in the hands of the manufacturers.

Thus manufacturers are particularly strong on the power dimension, as opposed to sources of power. This implies a 
Table 3 Non-coercive sources of power

\begin{tabular}{llll}
\hline $\begin{array}{l}\text { Retailer's non-coercive } \\
\text { sources of power: }\end{array}$ & Mean & $\begin{array}{l}\text { Manufacturer's non-coercive } \\
\text { sources of power }\end{array}$ & Mean \\
\hline Sales promotions & 6.54 & Advertising support & 6.68 \\
Advertising support & 5.73 & Support of sales promotions & 6.12 \\
Adequate notice before deliveries & 3.72 & Replenishment of shelf stock & 5.98 \\
Provision of market information & 3.19 & Provision of market information & 4.96 \\
Provision of product information & 3.12 & Provision of product information & 4.26 \\
\hline
\end{tabular}

\begin{tabular}{lclc} 
Table 4 Power & & & \\
\hline Power of retailers: & Mean & Power of manufacturers: & Mean \\
\hline Supply of house brands & 2.28 & Rules of delivery to warehouses & 4.04 \\
Delivery lead time & 2.05 & Advertising spending & 3.87 \\
Sponsorship for sales promotions & 2.05 & Sales promotions & 3.69 \\
Prices & 1.94 & Allocation of shelf space & 3.39 \\
Advertising spending & 1.91 & Markup percentages & 3.12 \\
Delivery policy & 1.76 & Placing of products & 3.08 \\
Product packaging & 1.25 & Amount of stock to hold & 2.88 \\
\hline
\end{tabular}

strong ability to change important retailing decisions taken by retailers, as opposed to the ability to impose punishments or to offer valuable assistances. This situation is well reflected in the words of one of the respondents to this study, a senior store manager for one of the most prominent retail chains, who said: 'We prefer working closer with suppliers and will rather take joint decisions on delivery times and allocations'. It is also consistent with the claims made by retailers and wholesalers such as Lamberti of Makro and Summers of Pick 'n Pay, who said that the power balance has swung back to manufacturers as a result of the concentration in that sector. Ironically, the effective use of their own sources of power by retailers has been one of the reasons forcing manufacturers to consolidate their own position. In addition poor economic conditions have forced the large corporations to consolidate their position through takeovers and rationalization programs.

The power position of manufacturers is consistent with the improving profit margins in this sector. Manufacturers are in the fortunate position of being able to force both primary food suppliers (e.g. farmers) and the retailers. The finding of the BTT study (1992: 6) is of particular relevance here, namely that the causes for sharply escalating food prices do not lie with either retailers or farmers. It cited input cost inflation at the food processing level ( $2 \%$ p.a.), Control Board schemes (1.596 p.a.), withdrawal of subsidies ( $0.3 \%$ p.a.) and removal of price control $(0.2 \%$ p.a.) as the main culprits in this regard.

In terms of the responses as to whether the ability of the other party to influence his company's business decisions has changed over the past ten years, both food manufacturers and retailers felt that the other party is today in a stronger position. The possible explanation for this contradiction may lie in the weaker ability of a single question to measure a complex construct such as power. More reliance should therefore be placed on the results of the multiple measures which have been used. A further explanation is that the respondents probably did not have the insight to distinguish between sources of power and power. This may have been a function of respondents being at widely varying levels of the organisations concerned. The reasons given by manufacturers for the change in the power relationship are that the retailers have become monopolistic, greater competition has weakened certain manufacturer's positions, poor trading conditions, and development of sophisticated information systems by retailers. Retailers give almost the same reasons, excluding sophisticated information systems, and adding stock shortages on key items and changing consumer profiles to their list.

Both manufacturers and retailers indicated that they expect the power relationship to change in the future. Reasons cited were:

- The claim by both parties of so-called monopolies being formed in the other sector.

- Difficult trading conditions.

- Claims by both parties of greater intra-group competition in their own sector.

- Claims by retailers of stock shortages on key items.

Retailers gave another reason with future implications, namely, changing consumer profiles. One sales manager for a prominent retail chain described this trend as follows: 'Although the ability of manufacturers to influence the business decisions of retailers is changing world wide, it is more evident in the South African market due to drastic changes in the socio-economic structures and different demands by different social groups. Remember that the consumer still has the greater ability to affect changes in any retail or manufacturing company'. The implication of this trend is that the retailer or manufacturer who adapts relatively better to the fast changing environment will have a power advantage in future.

\section{Conclusion}

The purpose of this study was to contribute to the debate around food distribution in South Africa by conducting research into the power balance between large retailers and the food processing or manufacturing sector. Specifically, the 
aim was to test the hypothesis that the power balance in food retailing in South Africa is currently in the hands of the manufacturer, and to characterize channel conflict and power in food distribution in South Africa.

It was found that retailers have the greatest strength in the coercive sources of power dimension, that is the ability to apply punishments which may hurt manufacturers, such as demanding comparatively low prices and delisting the products of manufacturers. This result is consistent with the claims by manufacturers that retailers make use of strong-arm tactics in cases of goal divergence.

In respect of non-coercive sources of power, neither retailers nor manufacturers have the upper hand. Sales promotions and advertising are the most important areas of assistance to both retailers and manufacturers.

However, manufacturers are strong on the power dimension, that is the ability to change important retailing decisions taken by retailers, such as decisions about sales promotions, advertising and product delivery. This result is consistent with claims by prominent retailers that the power balance in food retailing has swung back to the manufacturer. As a result retailers are now more inclined to co-operate with manufacturers regarding decisions on rack allocations and delivery times. The power position of manufacturers is consistent with their improving profit margins.

The power relationship is, however, perceived to be dynamic in nature and likely to change in future due to issues such as changing consumer profiles and the installation and commissioning of sophisticated information systems by retailers.

It is recommended that, using the results of this study as background, research should be conducted more directly into implications that the power relationship in the distribution channel has for the end consumer, and the changing nature of the power relationship.

\section{References}

Babbie, E. 1989. The practice of social research. Fifth edition. Belmont, California: Wadsworth Publishing Company.

Board on Tariffs and Trade. 1992. Preliminary report on an investigation into the price mechanism in the food chain with recommendations for its improvement. A discussion document submitted to the Minister of Trade and Industry Board on Trade and Tariffs. Pretoria.

Brown, J.R. \& Day, R. 1981. 'Measures of manifest conflict in distribution channels', Journal of Marketing Research, Vol. 18, August: 263-274.

Dahl, R.A. 1963. Modern political analysis. Englewood Cliffs, New York: Prentice Hall.

Emory, W.C. 1991. Business research methods. Fourth Edition. Boston, MA: Irwin.

Etgar, M. 1978. 'Intrachannel conflict and use of power', Journal of Marketing Research, Vol. 15, May: 273-274.

Financial Mail. 1991. 'The name of the game', April, 26: 94.

Financial Mail. 1991. 'The future of retailing', April 26: 14.

French, J.R.P. \& Raven, B. 1959. 'The bases of social Power'. In Dorwin Cartwright (ed.). Studies in social power. Ann Arbor: University of Michigan Press.

Gaski, J.F. 1984. 'The theory of power and conflict in channels of distribution', Journal of Marketing, Vol. 48, Summer: 9-29.
Hunt, S.D. \& Nevin, J.R. 1974. 'Power in a channel of distribution: sources and consequences', Journal of Marketing Research, Vol. 11, May: $186-193$.

James, K.B. 1985. Incentives in channel relations. Unpublished research report submitted in partial fulfillment of the requirements for the MBA degree. Johannesburg: University of the Witwatersrand.

Lusch, R.F. 1976. 'Sources of power: their impact on intrachannel conflict', Journal of Marketing Research, Vol. 13, November: 382-390

Lusch, R.F. \& Brown, J.R. 1982. 'A modified model of power in the marketing channel', Journal of Marketing Research, Vol. 19, August: $312-323$.

McGregor, S. \& McGregor, A. 1991. Quick reference to the JSE. Second edition. Johannesburg: Juta \& Co, Ltd.

Moore, R.A. 1989. 'Conceptual and empirical developments of marketing channel conflict', Journal of Marketing Management, Vol. 4, No. 3: 350-369.

Moore, R.A. 1990. 'The conflict gap in international channel relationships', Journal of Marketing Management, Vol. 6, No. 3: 225237.

Stern, L.W. \& El-Ansary, A.I. 1977. Marketing Channels. Englewood Cliffs, New York: Prentice Hall, Inc.

Wilemon, D.L. 1972. 'Power and negotiation strategies in marketing channels', The Southern Journal of Business, Vol. 7, February: $12-32$.

Wilkinson, I.F. 1974. 'Researching the distribution channels for consumer and industrial goods: the power dimension', Journal of the Market Research Society, Vol. 16, No. 1: 12-32.

\section{Appendix A Structure of the food dis- tribution channel in South Africa}

The structure of the food distribution channel in South Africa, identifying some of the major players, is depicted below. This was adopted from the BTT report (1992: 16), and extended by including information derived from various articles (such as Supplement to the Financial Mail, 26 April 1991: 14).

\begin{tabular}{lll} 
& \multicolumn{2}{l}{ Producers (Farmers) } \\
& (R20 206m) & \\
Players: & \\
Kanhym & \\
& Rainbow Chickens & \\
Imports/Exports & & Agricultural \\
& & Control Boards \\
& & Players: \\
& & Maize Board \\
& & Meat Board \\
& & Potato Board \\
& & Dairy Board \\
& & Egg Control \\
Interest groups \& & & Board \\
other institutions & Manufacturers' & \\
& Wholesale & \\
Players: & (R33 600m) & \\
& Players: &
\end{tabular}


Appendix A Structure of the food dis- Appendix A Structure of the food distribution channel in South Africa (cont.)

\begin{tabular}{ll}
\hline $\begin{array}{l}\text { Competition Board } \\
\text { Grocery Manufacturing } \\
\text { Ass. }\end{array}$ & Sanlam \\
Food Merchant Ass. & Barlow Rand \\
$\begin{array}{ll}\text { S.A. Sugar Association } \\
\begin{array}{l}\text { Organization of Livestock } \\
\text { Producers }\end{array}\end{array}$ & Tongaat Hulett \\
$\begin{array}{ll}\text { Department of Agri- } \\
\text { culture }\end{array}$ & $\begin{array}{l}\text { Rembrandt } \\
\text { Housewives League }\end{array}$ \\
& $\begin{array}{l}\text { Co-operatives, } \\
\text { Abakor, }\end{array}$ \\
& $\begin{array}{l}\text { Fresh produce } \\
\text { markets } \\
\text { Wholesalers }\end{array}$
\end{tabular}
tribution channel in South Africa (cont.)

Retailers

(R38 200m)

Players:

Pick 'n Pay

Checkers/Shoprite

Spar

Makro

OK

Consumer spending

(R42 000m) 